\title{
Increased Susceptibility to Bacterial Spot of Peach Trees Growing in Soil Infested with Criconemella xenoplax
}

\author{
D. Petra Shepard, Former Graduate Assistant, Eldon I. Zehr, Emeritus Professor, Department of Plant Pathology \\ and Physiology, and William C. Bridges, Professor, Department of Experimental Statistics, Clemson University, \\ Clemson, SC 29634
}

\begin{abstract}
Shepard, D. P., Zehr, E. I., and Bridges, W. C. 1999. Increased susceptibility to bacterial spot of peach trees growing in soil infested with Criconemella xenoplax. Plant Dis. 83:961-963.

Young Suwanee peach trees were planted in soil infested or not infested with the nematode Criconemella xenoplax. Five months after soil infestation, the leaves were inoculated with Xanthomonas campestris pv. pruni to measure the influence of nematode infestation on bacterial spot development. Bacterial spot lesions in inoculated leaves were more numerous and covered a greater leaf surface area for trees growing in nematode-infested soil than for those in noninfested soil. When the trees were growing in nematode-infested soil, the leaf area diseased was slightly greater on trees in nonsteamed field soil than in soil treated with aerated steam (57 to $62^{\circ} \mathrm{C}$ for $75 \mathrm{~min}$ ) prior to infestation with $C$. xenoplax. Results indicate that bacterial spot damage may become more severe on peach trees if the soil is infested with $C$. xenoplax than when nematodes have been suppressed.
\end{abstract}

Bacterial spot, caused by Xanthomonas campestris pv. pruni (proposed $X$. axonopodis pv. pruni) is a common disease of peach (Prunus persica) and other stone fruits in the southeastern United States. It is characterized by angular necrotic spots on leaves and dark, sunken lesions of variable size on fruit. Sometimes severe defoliation may follow leaf infection. The disease is especially severe on trees in light, sandy soils. These soils also are prone to infestation by the ring nematode, Criconemella xenoplax (=Mesocriconema xenoplax), especially in sites previously planted to peaches or other stone fruits.

The association in peach orchards of severe bacterial spot with $C$. xenoplax infestations suggested that this nematode might be a predisposing agent for this disease. $C$. xenoplax was found by Lownsbery et al. $(5,6)$ to increase the severity of bacterial canker on peach caused by Pseudomonas syringae pv. syringae. Mariana 2624 plum trees and young French prune trees on Myrobalan 29 C (Prunus cerasifera) root-

\section{Corresponding author: E. I. Zehr}

Current address of D. P. Shepard: 2209 Caldwell Place, Columbus, IN 47201.

Contribution No. 4427 of the South Carolina Agricultural Experiment Station, Clemson University.

Accepted for publication 6 July 1999.

Publication no. D-1999-0823-02R

This article is in the public domain and not copyrightable. It may be freely reprinted with customary crediting of the source. The American Phytopathological Society, 1999. stock in C. xenoplax-infested soil were more susceptible to both bacterial canker and Leucostoma canker caused by Leucostoma persoonii than in noninfested soil $(3,7)$. Additionally, C. xenoplax increases susceptibility to cold injury, which is a leading cause of death in the peach-treeshort-life disease complex (9).

Two other reports suggest a possible interaction between bacterial spot and soil infestation with $C$. xenoplax. Defoliation resulting from bacterial spot was greater for peach trees grown in nonfumigated, nematode-infested soil than in soil that had been fumigated with 1,2-dibromo-3-chloropropane (DBCP) (8). Likewise, defoliation of peach trees resulting from bacterial spot was less for trees on Lovell than on cannery seedling (Elberta) rootstock when grown in nematode-infested soil (12). Trees on Lovell rootstock appear to tolerate parasitism by $C$. xenoplax better than do those on cannery seedling or Nemaguard rootstocks $(6,10,12)$.

Our purpose was to study the interaction of C. xenoplax soil infestation and X. campestris pv. pruni on susceptibility of potted young peach trees to bacterial spot, and the effect of steaming the soil prior to planting on this relationship.

\section{MATERIALS AND METHODS}

Plant establishment and maintenance. One-year-old peach trees (cv. Suwanee, susceptible to bacterial spot) on Lovell rootstock were purchased from a commercial nursery. One-half of the trees were planted in $15-\mathrm{cm}$ round plastic pots filled with approximately $1,500 \mathrm{ml}$ of steamed (57 to $62^{\circ} \mathrm{C}$ for $75 \mathrm{~min}$ ) Lakeland sand (89\% sand, 5\% silt, 6\% clay). The re- maining trees were planted in nonsteamed Lakeland sand. Shoots and roots were pruned uniformly before planting, and cotton plugs were placed in the drain holes of all pots to retain soil during watering.

Beginning 11 weeks after planting, each tree was fertilized at 2-week intervals alternately with $100 \mathrm{ml}$ of a solution containing $45 \mathrm{~g}$ of $\mathrm{Ca}\left(\mathrm{NO}_{3}\right)_{2}$ and $15 \mathrm{~g}$ of $\mathrm{MgSO}_{4} \cdot 7 \mathrm{H}_{2} \mathrm{O}$ in 19 liters of water, or 100 $\mathrm{ml}$ of a solution containing $45 \mathrm{~g}$ of $15-0-14$ N-P-K fertilizer, $12 \mathrm{~g}$ of superphosphate, and $2 \mathrm{ml}$ of Stoller's Crop Mix (Stoller Chemicals, Houston, TX) in 19 liters of water. Miticides were applied as needed at labeled rates to all aerial portions of the plants, using dicofol (Kelthane), cyhexatin (Plictran), dienochlor (Pentac), or hexakis (Vendex). Plants were grown under natural light in a greenhouse at ambient temperatures ranging from 20 to $30^{\circ} \mathrm{C}$.

Nematode inoculation. Nematodes used for inoculum were extracted by centrifugal flotation (4) from established cultures of $C$. xenoplax on roots of Nemaguard peach seedlings growing in greenhouse culture pots. Three months after planting, approximately $5,000 \mathrm{C}$. xenoplax individuals (larvae and adult females) in a 20-ml aqueous suspension were added to each of 48 trees planted in unsteamed soil and to each of 48 trees in steamed soil. The nematode suspension was dispensed equally into four holes in the soil; holes were $1 \mathrm{~cm}$ diameter, $10 \mathrm{~cm}$ deep, and $5 \mathrm{~cm}$ from the tree stem. The holes were filled with tap water after inoculation to aid infiltration of nematodes into the soil. Forty-eight trees in steamed soil and 48 in nonsteamed soil were not inoculated with $C$. xenoplax; tap water only was added to holes in soil around these control trees.

Bacterial inoculum. An isolate of $X$. campestris pv. pruni obtained from apricot and virulent in peach (received courtesy of C. C. Reilly, USDA Fruit and Tree Nut Research Laboratory, Byron, GA) was maintained on $2.3 \%$ nutrient agar and transferred weekly. Inoculum was prepared from 48-h cultures grown on yeast extractdextrose-calcium carbonate agar slants at $27^{\circ} \mathrm{C}$. Bacterial suspensions were prepared in sterile distilled water and adjusted turbidimetrically to $10^{7} \mathrm{CFU} / \mathrm{ml}$ (60 to $64 \%$ transmission at $620 \mathrm{~nm}$ on a Bausch \& Lomb Model 20 Spectrophotometer, Bausch \& Lomb, Rochester, NY). The titer 
of inoculum for each experiment was determined by spreading $0.1 \mathrm{ml}$ of an appropriate dilution on the surface of XPSM selective medium (2). Colonies were counted after incubating plates at $27^{\circ} \mathrm{C}$ for 7 days.

Inoculation of peach leaves. Inoculation with $X$. campestris pv. pruni commenced 5 months after nematode infestation of the soil, when the young trees were 0.6 to $0.8 \mathrm{~m}$ tall, pruned to a single stem. For inoculation of peach leaves with $X$. campestris pv. pruni, 32 potted trees (eight each from the nematode-inoculated or -noninoculated, steamed or nonsteamed soil described previously) were randomly selected. Four plants from each group of eight were inoculated; the other four served as control plants. Immediately prior to inoculation, trees were maintained at $27^{\circ} \mathrm{C}$ and $100 \%$ relative humidity for $48 \mathrm{~h}$ in a dew chamber (Percival Model E-54UDL, Percival Manufacturing Co., Boone, IA), with a 16-h photoperiod, to induce water congestion. Inoculum was applied to the abaxial side of leaves with a Thayer and Chandler Model E artist's airbrush (Thayer and Chandler, Inc., Chicago, IL) operated under an air pressure of $68.9 \mathrm{kPa}$. Leaves were sprayed to runoff with an approximate delivery of $0.2 \mathrm{ml}$ of bacterial suspension per leaf. Each leaf was supported with a sterile paper towel to absorb excess inoculum. All leaves per plant were inoculated or, for the control plants, sprayed with sterile distilled water.

Trees were held in darkness at $30^{\circ} \mathrm{C}$ and $100 \%$ relative humidity in Percival dew chambers for $48 \mathrm{~h}$ as a postinoculation wetness period. Then the trees were placed in a growth room at $30^{\circ} \mathrm{C}$ with a $16-\mathrm{h}$ photoperiod for 14 days. Fluorescent lighting in the growth room provided photosynthetically active radiation measured between 240 and $300 \mu \mathrm{E} / \mathrm{m}^{2} / \mathrm{s}^{1}$ (LI-190SB quantum sensor, Li-Cor, Inc., Lincoln, NE). Symptoms were evaluated after 5 and 15 days and recorded as percent leaf area

Table 1. Necrotic leaf area and defoliation of peach trees after infection by Xanthomonas campestris pv. pruni at $30^{\circ} \mathrm{C}$ as affected by Criconemella xenoplax infestation in steamed or nonsteamed soil

\begin{tabular}{lccc}
\hline Treatments & $\begin{array}{c}\text { Leaf area } \\
\text { diseased }(\%)^{\mathbf{x}}\end{array}$ & \% Defoliation & $\begin{array}{c}\text { C. } \text { xenoplax/ } \\
\mathbf{1 0 0} \mathbf{~ c m}^{\mathbf{3}} \text { soil }^{\mathbf{y}}\end{array}$ \\
\hline Nonsteamed soil & & & \\
C. xenoplax + X. campestris pv. pruni ${ }^{\mathrm{z}}$ & $56.5 \mathrm{a}$ & $20.0 \mathrm{ab}$ & $1,435 \mathrm{a}^{\mathrm{z}}$ \\
C. xenoplax & $0.0 \mathrm{~d}$ & $10.0 \mathrm{bc}$ & $1,771 \mathrm{a}$ \\
X. campestris pv. pruni & $21.5 \mathrm{c}$ & $10.0 \mathrm{bc}$ & $0 \mathrm{~b}$ \\
Control & $0.0 \mathrm{~d}$ & $0.0 \mathrm{c}$ & $0 \mathrm{~b}$ \\
Steamed soil & & & \\
C. xenoplax + X. campestris pv. pruni ${ }^{\mathrm{z}}$ & $47.7 \mathrm{~b}$ & $25.0 \mathrm{a}$ & $1,531 \mathrm{a}$ \\
C. xenoplax & $0.0 \mathrm{~d}$ & $8.0 \mathrm{bc}$ & $1,968 \mathrm{a}$ \\
X. campestris pv. pruni & $23.3 \mathrm{c}$ & $0.0 \mathrm{c}$ & $0 \mathrm{~b}$ \\
Control & $0.0 \mathrm{~d}$ & $0.0 \mathrm{c}$ & $0 \mathrm{~b}$ \\
\hline
\end{tabular}

${ }^{\mathrm{x}}$ Values are means from six experiments with four replicates per treatment 15 days after inoculation with $X$. campestris pv. pruni. Experimental unit was a single tree, with six leaves sampled from each tree. Means followed by the same letter are not significantly different in paired comparisons.

${ }^{y}$ Number of $C$. xenoplax at 5 to 6 months after soil inoculation. Initial population was 334 nematodes per $100 \mathrm{~cm}^{3}$ soil

${ }^{\mathrm{z}}$ Trees were inoculated with $X$. campestris pv. pruni 5 to 6 months after soil inoculation with $C$. xenoplax.
C. xenoplax-infested soil were not visually different from control trees prior to inoculation with $X$. campestris pv. pruni. Natural, nonsteamed Lakeland soil contained eight or fewer C. xenoplax per $100 \mathrm{~cm}^{3}$ soil throughout the repeated tests.

Effect of $C$. xenoplax infection. $C$. xenoplax became established on the peach seedlings, and populations increased an average of four- to sixfold during the 5month period between nematode inoculation of the soil and bacterial inoculation of leaves. Infection by $C$. xenoplax significantly $(P \leq 0.05)$ increased bacterial spot severity on peach leaves in both steamed and nonsteamed soil (Table 1). The percent leaf area that became necrotic when tree roots were infected with $C$. xenoplax was slightly greater in nonsteamed than in steamed soil (Table 1). Effects of nematode parasitism on bacterial spot were expressed as increases in leaf area diseased. The increased areas of necrosis represented larger and more numerous lesions, but data on lesion size and numbers were not recorded. The percentage of leaf area diseased in nematode-infested soil was more than twice that in noninfested soil, whether steamed or not (Table 1). Lesions were larger and continued to expand on trees in infested soil, whereas in noninfested soil, lesions were smaller and restricted. Leaves of trees in nematode-infested soil had large (7 to $8 \mathrm{~mm}$ diameter), water-soaked, angular, dark lesions that spread and coalesced, resulting in irregular blackened patches up to $1 \mathrm{~cm}^{2}$ in various positions on the leaves.

Defoliation was greater when trees were grown in C. xenoplax-infested soil and inoculated with $X$. campestris pv. pruni than for control trees, which had no defoliation. Defoliation of trees grown in $C$. xenoplax-infested soil occurred about 1 week after inoculation with $X$. campestris pv. pruni and usually was preceded by an abrupt chlorosis of the leaf margins, especially near petioles. In noninfested soil, defoliation began 10 to 14 days after inoculation with bacteria. Defoliation and leaf chlorosis did not appear in noninoculated control plants. Variation in nematode populations within treatments and between repeated experiments did not permit statistically reliable correlations to be made between nematode populations and disease severity nor between nematode populations and root density or necrosis.

Effect of steam-pasteurization. There was no significant difference between bacterial spot severity on trees grown in steamed soil and on those grown in nonsteamed soil in the absence of $C$. xenoplax (Table 1). Symptom development was similar in both treatments; dark, watersoaked lesions appeared 3 days after inoculation with bacteria. Tip and marginal necroses appeared in 3 days on immature, young leaves and were seen on older leaves in approximately 5 days. Water- 
soaked lesions became black and dried within 2 days and did not spread. Trends related to treatment at 5 days were the same as at 15 days; data at 15 days only are presented in Table 1. Lesions averaged 3 to $5 \mathrm{~mm}$ in diameter and were scattered over the leaf blade. Defoliation did not occur on trees grown in steamed soil in the absence of $C$. xenoplax. Mild defoliation (up to 10\%) occurred when either the nematode or the bacteria individually infected the plants, but defoliation increased to 20 to $25 \%$ when both organisms were present (Table 1).

\section{DISCUSSION}

In the experiments described here, peach trees growing in soil infested with $C$. xenoplax had greater bacterial spot severity than did those in noninfested soil. Nematode infestation resulted in a larger percentage of leaf area diseased and larger and more numerous lesions after inoculation with $X$. campestris pv. pruni. The symptomatic leaf area more than doubled when soil was infested with $C$. xenoplax, whether in nonsteamed or steamed soil, compared with noninfested soil. Leaves responded to inoculation with $X$. campestris pv. pruni and $C$. xenoplax infestation with large ( 7 to $8 \mathrm{~mm}$ diameter), spreading lesions. Some healthy and diseased leaves abscised, but many severely diseased leaves ( $>50 \%$ leaf area diseased) remained attached to trees throughout the experiment. There was no apparent relationship between defoliation and disease severity of individual leaves, but usually peach trees responded to infection by $X$. campestris pv. pruni, C. xenoplax, or both by shedding some leaves. C. xenoplax infestation was not essential for infection by $X$. campestris pv. pruni, however. Infection of leaves occurred regardless of soil conditionsteamed or nonsteamed, infested or noninfested. Premature defoliation following leaf infection occurred earlier and more often in trees grown in C. xenoplax-infested soil, corroborating the report by Nesmith and Dowler (8). There was no apparent relationship between defoliation and disease severity, which supports the field observation of Werner et al. (11).

Some reports $(5,7)$ suggest that $C$. xenoplax affects susceptibility to Pseudomonas syringae directly through feeding damage to roots, which subsequently results in water stress throughout the tree. Mojtahedi et al. (7) found that water stress was higher in leaves of $C$. xenoplax-infected trees than for trees in noninfested soil. The data reported here do not refute a relationship between water stress in the tree and susceptibility to $X$. campestris pv. pruni infection, but there appears to be an additional host response to feeding by $C$. xenoplax that permits extensive development of bacterial spot symptoms. There was no visible evidence of water stress in the trees used in this study.

Lownsbery et al. (5) found that the full effect of $C$. xenoplax on bacterial canker was evident only after three growing seasons. Mojtahedi et al. (7) conducted their studies for 2 years, which allowed adequate time for extensive nematode feeding, root injury, and the development of aboveground symptoms such as bacterial canker. In our experiments, $C$. xenoplax and peach trees were in association for only 5 to 6 months. Other aspects of bacterial spot development, such as canker initiation, might have become evident in experiments of longer duration.

The injurious effects of $C$. xenoplax extend much further than their damage to fine roots of peach trees and other Prunus spp. Their feeding increases susceptibility to Pseudomonas syringae pv. syringae, resulting in more severe damage from bacterial canker $(5,6)$, greater susceptibility to cold injury in the peach tree short-life syndrome (9), heightened damage from Leucostoma canker (3), and now, as we have shown here, increased susceptibility to bacterial spot. The need for management of C. xenoplax in peach orchards probably is more imperative because of these effects than for the direct injurious effects of nematode feeding on roots. The mechanism(s) involved in predisposition to these other diseases or disorders has not been explained and needs further investigation.

The effect of $C$. xenoplax on bacterial spot severity demonstrated here adds further impetus for control of C. xenoplax in peach orchards. Rootstocks that are susceptible to $C$. xenoplax, if used in nematode-infested soil, might result in increased susceptibility to bacterial spot in the scion. The peach cultivar used in this research (Suwanee) is very susceptible to bacterial spot and is no longer widely planted in commercial orchards. We do not know whether other peach cultivars, resistant or susceptible to bacterial spot, respond in a similar way to that of Suwanee, but the potential exists for resistant cultivars to become susceptible if planted in soil infested with $C$. xenoplax and for bacterial spot-susceptible cultivars to become more susceptible. The linkage between sandy soils, infestation with $C$. xenoplax, and bacterial spot development should be heeded when commercial orchard sites are selected. Additionally, test plots used for evaluating bacterial spot susceptibility of new cultivars should be checked for infestation by $C$. xenoplax, and this factor should be considered when determination of bacterial spot susceptibility is made.

\section{LITERATURE CITED}

1. Byrd, D. W., Jr., Barker, K. R., Ferris, H., Nusbaum, C. J., Griffin, W. E., Small, R. H., and Stone, C. A. 1976. Two semi-automatic elutriators for extracting nematodes and certain fungi from soil. J. Nematol. 8:206-212.

2. Civerolo, E. L., Sasser, M., Helkie, C., and Burbage, D. 1982. Selective medium for Xanthomonas campestris pv. pruni. Plant Dis. 66:39-43.

3. English, H., Lownsbery, B. F., Schick, F. J., and Burlando, T. 1982. Effect of ring and pin nematodes on the development of bacterial canker and Cytospora canker in young French prune trees. Plant Dis. 66:114-116.

4. Jenkins, W. R. 1964. A rapid centrifugalflotation technique for separating nematodes from soil. Plant Dis. Rep. 48:692.

5. Lownsbery, B. F., English, H., Moody, E. H., and Shick, F. J. 1973. Criconemoides xenoplax experimentally associated with a disease of peach. Phytopathology 63:994-997.

6. Lownsbery, B. F., English, H., Noel, G. R., and Schick, F. J. 1977. Influence of Nemaguard and Lovell rootstocks and Macroposthonia xenoplax on bacterial canker of peach. J. Nematol. 9:221-224.

7. Mojtahedi, H., Lownsbery, B. F., and Moody, E. H. 1975. Ring nematodes increase development of bacterial cankers in plums. Phytopathology 65:556-559.

8. Nesmith, W. C., and Dowler, W. M. 1975. Soil fumigation and fall pruning related to peach tree short life. Phytopathology 65:277-280.

9. Nyczepir, A. P., Zehr, E. I., Lewis, S. A., and Harshman, D. C. 1983. Short life of peach trees induced by Criconemella xenoplax. Plant Dis. 67:507-508.

10. Ritchie, D. F., and Clayton, C. N. 1981. Peach tree short life: A complex of interacting factors. Plant Dis. 65:462-469.

11. Werner, D. J., Ritchie, D. F., Cain, D. W., and Zehr, E. I. 1986. Susceptibility of peaches and nectarines, plant introductions, and other Prunus species to bacterial spot. HortScience 21:127-130.

12. Zehr, E. I., Miller, R. W., and Smith, F. H. 1976. Soil fumigation and peach rootstocks for protection against peach tree short-life. Phytopathology 66:689-694.

13. Zehr, E. I., Shepard, D. P., and Bridges, W. C., Jr. 1996. Bacterial spot of peach as influenced by water congestion, leaf wetness duration, and temperature. Plant Dis. 80:339-341. 